\title{
MASTER
}

\section{THE EFFECT OF REDUCED BOILER WATER TEMPERATURE ON CYCLE EFFICIENCY}

\author{
J.E. BATEY AND T.W. ALLEN
}

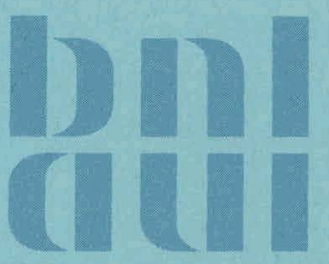

July 1977

DEPARTMENT OF ENERGY AND ENVIRONMENT

BROOKHAVEN NATIONAL LABORATORY

ASSOCIATED UNIVERSITIES, INC.

UNDER CONTRACT NO. EY-76-C-02-0016 WITH THE

UNITED STATES DEPARTMENT OF ENERGY 


\section{DISCLAIMER}

This report was prepared as an account of work sponsored by an agency of the United States Government. Neither the United States Government nor any agency Thereof, nor any of their employees, makes any warranty, express or implied, or assumes any legal liability or responsibility for the accuracy, completeness, or usefulness of any information, apparatus, product, or process disclosed, or represents that its use would not infringe privately owned rights. Reference herein to any specific commercial product, process, or service by trade name, trademark, manufacturer, or otherwise does not necessarily constitute or imply its endorsement, recommendation, or favoring by the United States Government or any agency thereof. The views and opinions of authors expressed herein do not necessarily state or reflect those of the United States Government or any agency thereof. 


\section{DISCLAIMER}

Portions of this document may be illegible in electronic image products. Images are produced from the best available original document. 
BNL 50712

UC-95d

(Energy Conservation-Buildings

and Community Systems - TID-4500)

\title{
THE EFFECT OF REDUCED BOILER WATER TEMPERATURE ON CYCLE EFFICIENCY
}

\author{
J.E. BAtey ANd T.W. Allen
}

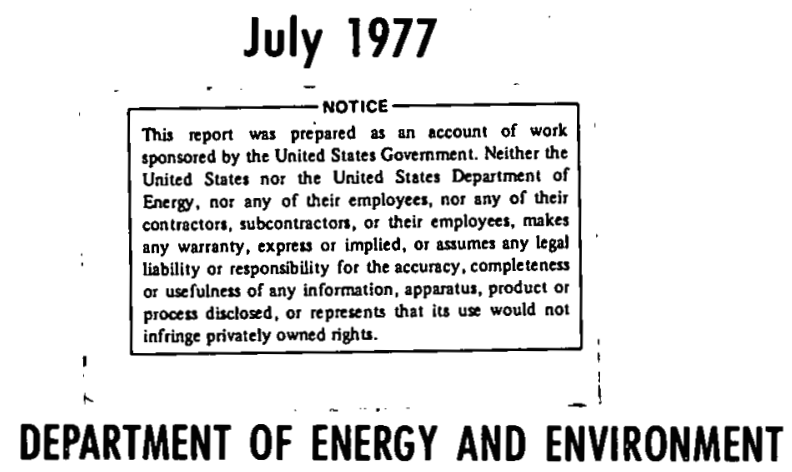

BROOKHAVEN NATIONAL LABORATORY

UPTON, NEW YORK 11973 
NOTICE

This report was prepared as an account of work sponsored by the United States Government. Neither the United States nor the United Statcs Department of Energy (DOE), nor any of their employees, nor any of their contractors, subcontracturs, or thcir eniployees, makes any warranty, express or implied, or assumes any legal liability or responsibility for the acouracy, inilpleteieneso or usctuliness of any intormation, apparatus, product or process disclosed, or represents that its use would not infringe privately owned rights.

Printed in the United States of America

Available from

National '1'echnical İnformation Service

U.S. Department of Commerce

5285 Port Royal Road

Springfield, VA 22161

Price: Printed Copy $\$ 4.00$; Microfiché $\$ 3.00$

October 1977

580 copies 


\section{ABSTRACT}

Tests were performed on a "typical" residential hot water boiler to evaluate the energy saving potential of reduced boiler water temperature. A significant reduction of annual fuel consumption was determined based on detailed efficiency measurements combined with the BNL Seasonal Performance Evaluation Computational Program. The energy saving has been attributed to reduced off-cycle heat losses resulting from the lower boiler operating temperature. 
TABLE OF CONTENTS

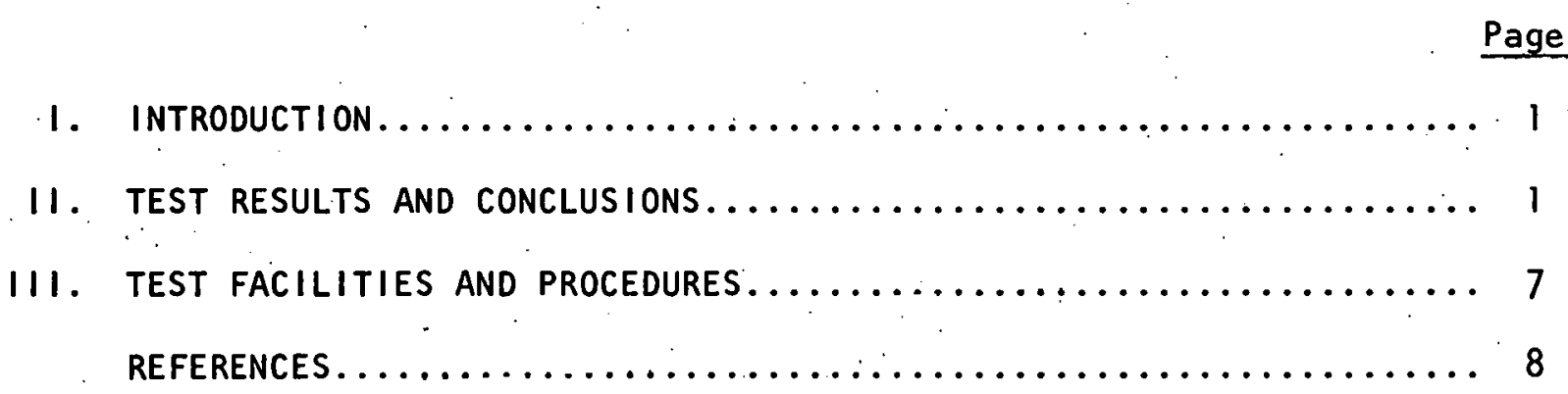

Page 7 8 


\section{INTRODUCTION}

The burner-Boiler/Furnace Efficiency Test Facility at Brookhaven National Laboratory is evaluating the energy-saving potential of various retrofit modifications for residential heating equipment. A preliminary list of proposed refit actions is included in Fig. 1. Some of these modifications will be evaluated as part of the ongoing national program in which equipment manufacturers, inventors, and developers voluntarily submit high efficiency equipment to BNL for testing.

Currently, the schedule of equipment to be tested includes: retentionhead burners; blue flame burners, reduced firing rate burners (less than 0.5 gallons per hour), variable firing rate.burners, convective stack dampers, purgeable low mass boilers, water-fuel emulsion burners, and stack heat reclaimers. Other refit possibilities that will be tested at BNL include: reduced burner firing rate, variable boiler water set-point, "continuous" water circulator operation, outside air ducting for combustion air, outside boiler installation, and flue gas turbulators.

The present report summarized the results of tests conducted to establish the relationship between off-cycle boiler heat loss and reduced boiler temperature (see Fig. 1-2a). It was found that reducing the boiler water temperature during burner on-off cycling resulted in substantial fuel savings as a result of decreased off-cycle flue losses. When the boiler water average outlet temperature decreased from $185^{\circ} \mathrm{F}$ to $150^{\circ} \mathrm{F}$, burner off-cycle heat losses were reduced by 30 percent, corresponding to an increase in overall efficiency of 6 percent.

\section{TEST RESULTS AND CONCLUSIONS}

Overall efficiency versus burner fractional "'on" time is plotted in Fig. 2 for the two average boiler temperatures tested. From these curves it is evident that heat losses occurring during the burner "off" cycle are reduced by lowering the boiler temperature for all burner fractional "on" times. These data are presented in Table 1 : 


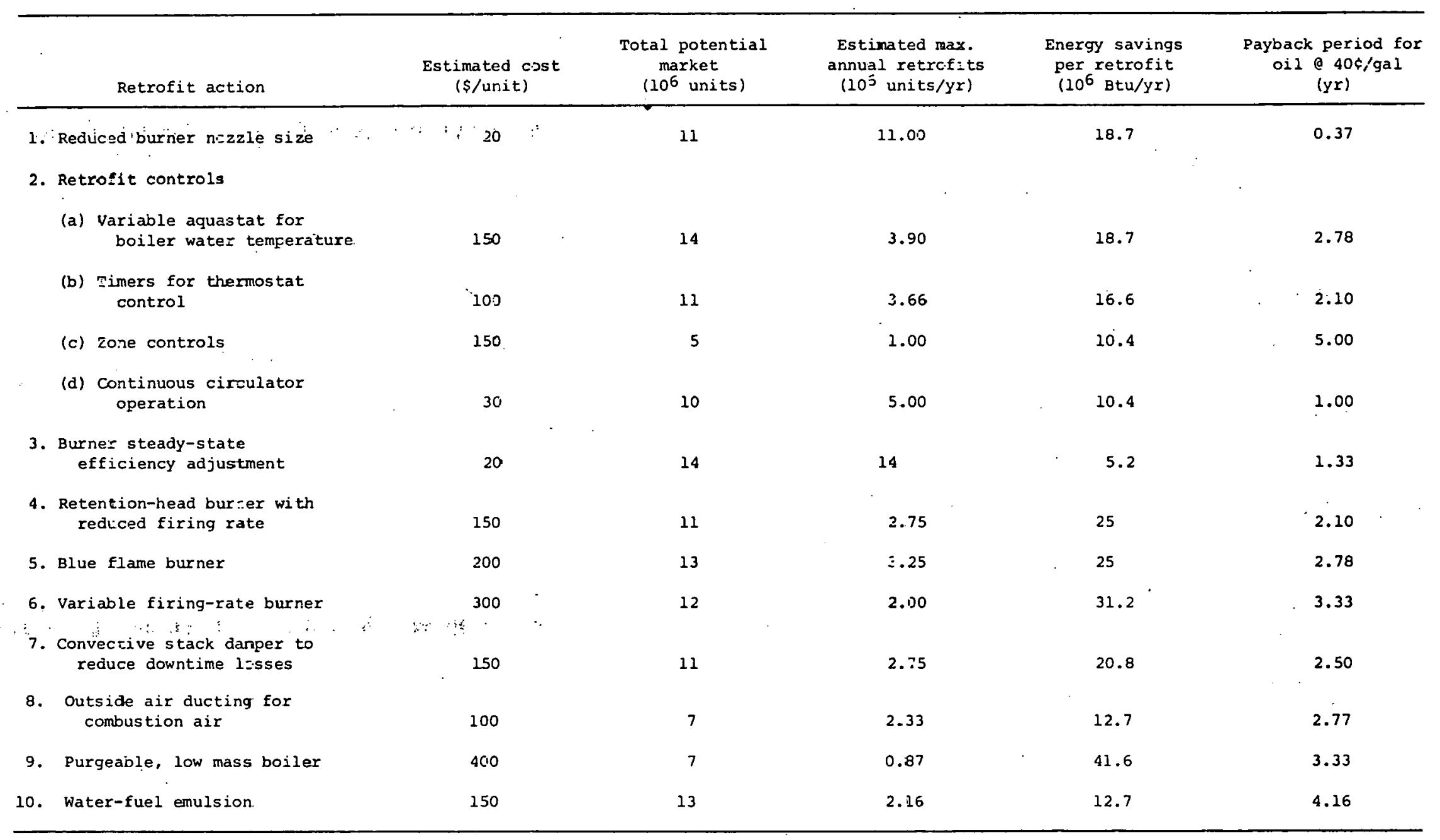

Notes: (1) Savings from retrofit actions are not additive. (21 Options 6 to 10 have less development.

*Based on a total of $14 \times 10^{6}$ single family units ard oil consurption of $500 \times 10^{6} \mathrm{bbl} / \mathrm{yr}$.

Figure 1. Retrofit oftions for oil-fired residential heating equipment. 


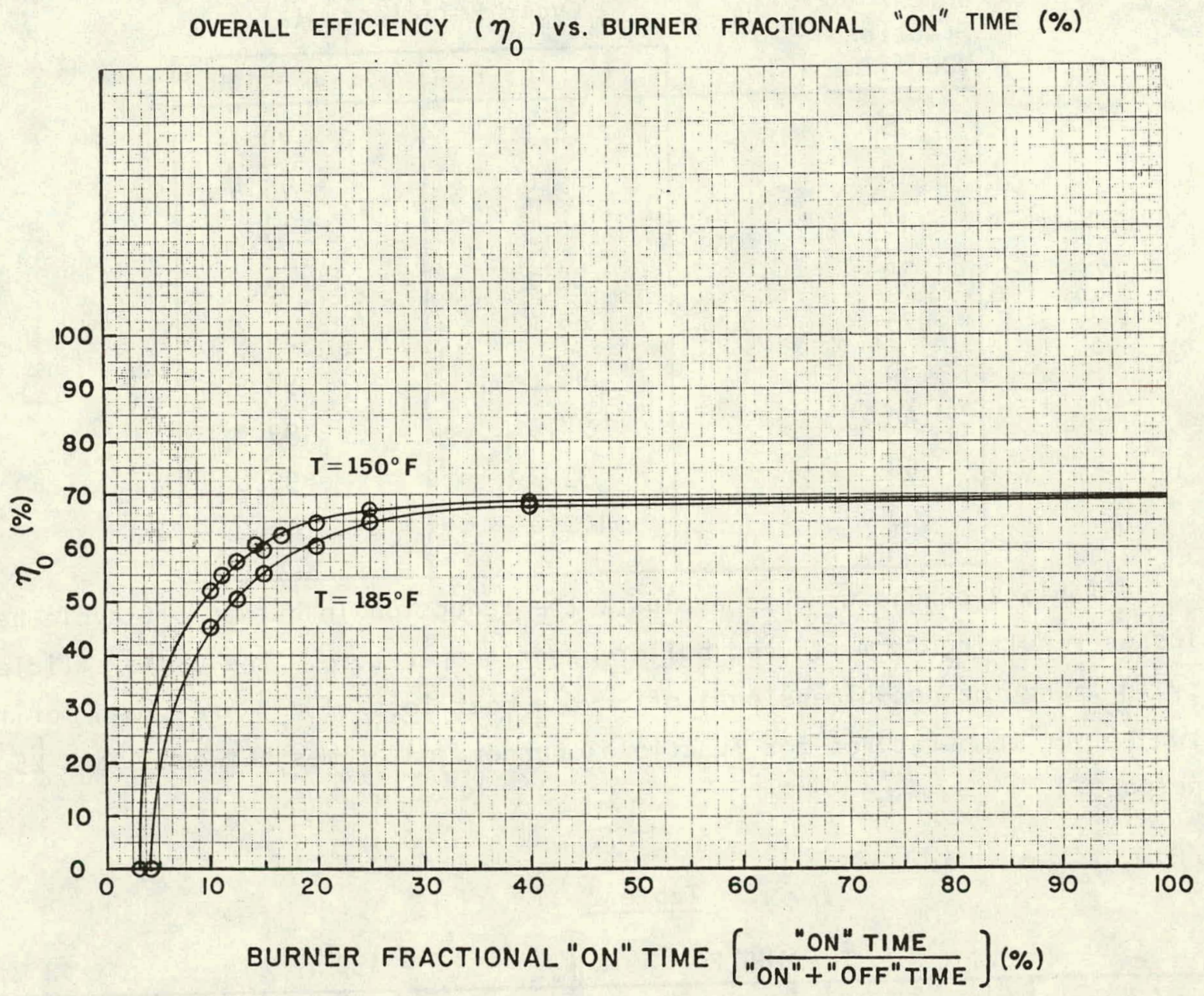

Figure 2. Effect of boiler temperature on cycle efficiency. 
Table 1

\begin{tabular}{|c|c|c|}
\hline \multirow{2}{*}{$\begin{array}{l}\text { Burner } \\
\text { Fractional } \\
\text { "On" Time (\%) }\end{array}$} & \multicolumn{2}{|c|}{ Cycle Efficiency (\%) } \\
\hline & $\overline{\mathrm{T}}=185^{\circ} \mathrm{F}$ & $\overline{\mathrm{T}}=150^{\circ} \mathrm{F}$ \\
\hline 5 & 18.1 & 40.1 \\
\hline 10 & 65.0 & 75.4 \\
\hline 15 & 80.5 & 87.2 \\
\hline 20 & 88.2 & 93.1 \\
\hline 25 & 92.8 & 96.6 \\
\hline 30 & 95.8 & 98.9 \\
\hline 40 & 98.3 & 99.5 \\
\hline 60 & 99.2 & 99.8 \\
\hline 100 & 100.0 & 100.0 \\
\hline
\end{tabular}

Table 2 can be used to evaluate the reduction in burner off-cycle heat losses resulting from reduced boiler water temperature. The cycle efficiency $\left(n_{c}\right)$ and the non-dimensional off-cycle heat loss $\left(1-n_{c}\right)$ are shown for the two boiler temperatures for fractional burner "on" times between 5 and 25 percent.

\section{Table 2}

\begin{tabular}{|c|c|c|c|c|c|}
\hline $\begin{array}{l}\text { Fractional } \\
\text { Burner } \\
\text { "On" Time }\end{array}$ & $\begin{array}{l}\text { Cycle } \\
\text { Efficiency } \\
\%\left(n_{n_{n}}\right)\end{array}$ & $\begin{array}{l}\text { Non- } \\
\text { dimensional } \\
\text { "Off" Cycle } \\
\text { Heat Loss } \\
\left(1-n_{c}\right)\end{array}$ & $\begin{array}{l}\text { Cycle } \\
\text { Effi- } \\
\text { ciency } \\
\%\left(\eta_{c}\right)\end{array}$ & $\begin{array}{l}\text { Non- } \\
\text { dimensional } \\
\text { "Off" Cyc.le } \\
\text { Heat Loss } \\
\left(1-\eta_{c}\right)\end{array}$ & $\begin{array}{l}\text { Percent } \\
\text { Reduction } \\
\text { "Off" Cycle } \\
\text { Heat Loss } \\
(\%)\end{array}$ \\
\hline 5 & 18.1 & 0.812 & 40.1 & 0.599 & 26 \\
\hline 10 & 65.0 & 0.350 & 75.4 & 0.246 & 30 \\
\hline 15 & 80.5 & 0.195 & 87.2 & 0.128 & 34 \\
\hline 20 & 88.2 & 0.118 & 93.1 & 0.069 & 42 \\
\hline 25 & 92.8 & 0.072 & 96.6 & 0.034 & 53 \\
\hline
\end{tabular}

Note: $n_{\text {overall }}=\eta_{\text {steady state }}{ }^{x n_{\text {cycle }}}$ 
A Seasonal Performance Evaluation (SPE) analysis has been performed using the BNL Computer Program to evaluate the actual reduction in annual fuel consumption resulting from lower boiler operating temperature. The SPE analysis uses hourly temperature data (for a particular geographic location) and the measured efficiencies to calculate the total amount of fuel consumed by the heating unit for a particular design heat load as a function of fuel firing rate (fuel nozzle size). A ten-year average of hourly temperature data for New York City, Kennedy Airport was used with a design heat load of 50,000 Btu per hour, and 40 gallons per day of domestic hot water. Based on field data, a fuel firing rate of 1.1 gallons per hour can be assumed, representing an over-firing rate of about 100 percent.

The lower boiler water temperature resulted in a reduction of offcycle heat loss by 30 percent, producing a six percent increase of overall efficiency (from 57.6 to 61.4 percent). The total quantity of fuel consumed dropped by 90 gallons per year (from 1440 to 1350) for identical space heat and domestic hot water loads, as a direct result of reduced boiler operating temperature.

A simple heat flow calculation can be used to approximate the above results. If we assume that the air mass flow rate through the boiler remains constant for the two boiler temperatures, (a reasonable assumption) we can demonstrate that the off-cycle heat loss rates $(\dot{H})$ are proportional to the boiler water temperature.

$$
\dot{H}=\dot{m}_{a i r} c_{p} \Delta T
$$

where:

$$
\begin{aligned}
\dot{H}= & \text { is the boiler off-cycle heat loss } \\
& \text { rate (BTUH) }
\end{aligned}
$$

$$
\begin{aligned}
& m_{\text {air }} \text { - is the air mass flow rate through } \\
& \text { the boiler during the "off" period } \\
& \text { (pounds/hr). }
\end{aligned}
$$




$$
\begin{gathered}
C_{P}-\left(\frac{B t u}{\text { pound }-{ }^{O} F}\right) \\
\Delta T-\text { is the temperature rise of the air } \\
\text { passing through the boiler during } \\
\text { the "off" period }\left({ }^{\circ} \mathrm{F}\right)
\end{gathered}
$$

The off-cycle heat loss rate is equal to the product of the air mass flow rate through the boiler, the heat capacity of the air and the temperature rise of the air passing through the boiler.

For the present case:

$$
\begin{aligned}
& \dot{H}_{1}=\dot{m}_{\text {air }} C_{P}(185-70)=M(115) \\
& \dot{H}_{2}=\dot{m}_{\text {air }} C_{P}(150-70)=M(80)
\end{aligned}
$$

The reduction in off-cycle heat loss rate for lower boiler temperature can be calculated from the above (assuming $M=$ constant):

$$
\dot{\Delta H}=\frac{115-80}{115}=30 \%
$$

This agrees closcly with the measured efficiency improvement. Therefore, for relatively constant off-cycle air flow rates through the boiler we can approximate the temperature of the air leaving the boiler to be equal to the average boiler water outlet temperature. Additional measurements are required to substantiate and develop this relationship.

The quantitative relationship between boiler temperature and off-rycle ingses has bcen establlshed by these tests. It has been shown that reducing boiler water outlet temperature from $185^{\circ} \mathrm{F}$ to $150^{\circ} \mathrm{F}$ resulted in substantial reduction of burner off-cycle heat losses. While the above calculations were carried out for a fixed boller temperature of $150^{\circ} \mathrm{F}$, in an actual application the boiler water temperature would be expected to be variable 
(perhaps from 100 to $200^{\circ} \mathrm{F}$ ) to accommodate varying heat loads.

This could be accomplished by an automatic boiler temperature controller that would sense the outside temperature and select a boiler water temperature that is just sufficient to meet the heating load of the house. Another way to accomplish this would be for the homeowner to adjust the boiler water temperature manually, in each climatic season (or more often), to a temperature that will satisfy the heating load of the house. By varying the boiler temperature automatically (or manually), the resulting fuel savings would be larger than 6 percent. A more detailed analysis would be required to evaluate fuel savings resulting from variable aquastat operation.

This concept is directly applicable to all hydronic heating boilers that maintain a minimum temperature in order to supply domestic hot water utilizing an indirect (internal or external) water heating coil.

\section{TEST FACILITIES AND PROCEDURES}

The heating equipment tested can be described as a "typical" residential boiler of single pass, vertical fire tube, dry base design with a low speed, nonretention heat burner.

A detailed description of the test facilities and procedures are provided in the Findings Report Reference Manual. ${ }^{2}$ For the high temperature cycles, the above mentioned procedures were followed exactly. For the low temperature cycles, the water flow "on" time was increased to provide reduced outlet water temperature, during cycling. All other procedures remained unchanged. 


\section{References}

1. J. Batey, V. Gazérro, F. J. Salzano, A. L. Berlad, Energy Management in Residential and Small Commercial Buildings, Annual Report, Fiscal Year 1976, Formal Report. (BNL 50576)

2. J. Batey, R. Hoppe, F. J. Salzano, A. L. Berlad, Hydronic Equipment Findings Report Reference Manual, July 1977, Formal Report. (BNL 50644) 